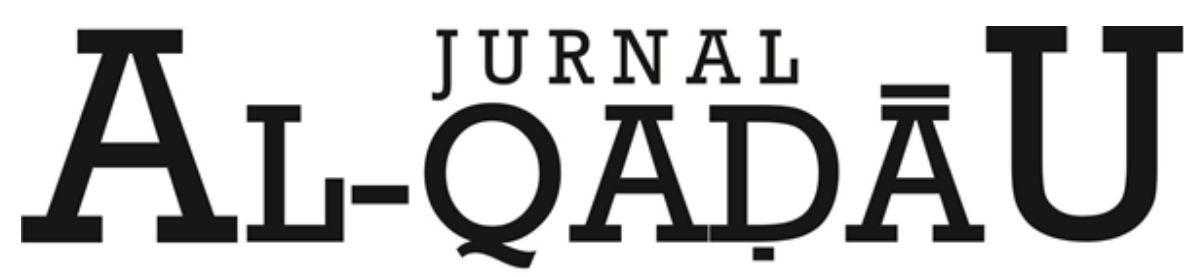

PERADILAN dan HUKUM KELUARGA ISLAM

\title{
Ghibah Perspektif Sunnah
}

Ghibah Perspective Sunnah

Musyfikah Ilyas

Dosen Fakultas Syariah dan Hukum UIN Alauddin Makassar

Email: musyfikah.ilyas@gmail.com

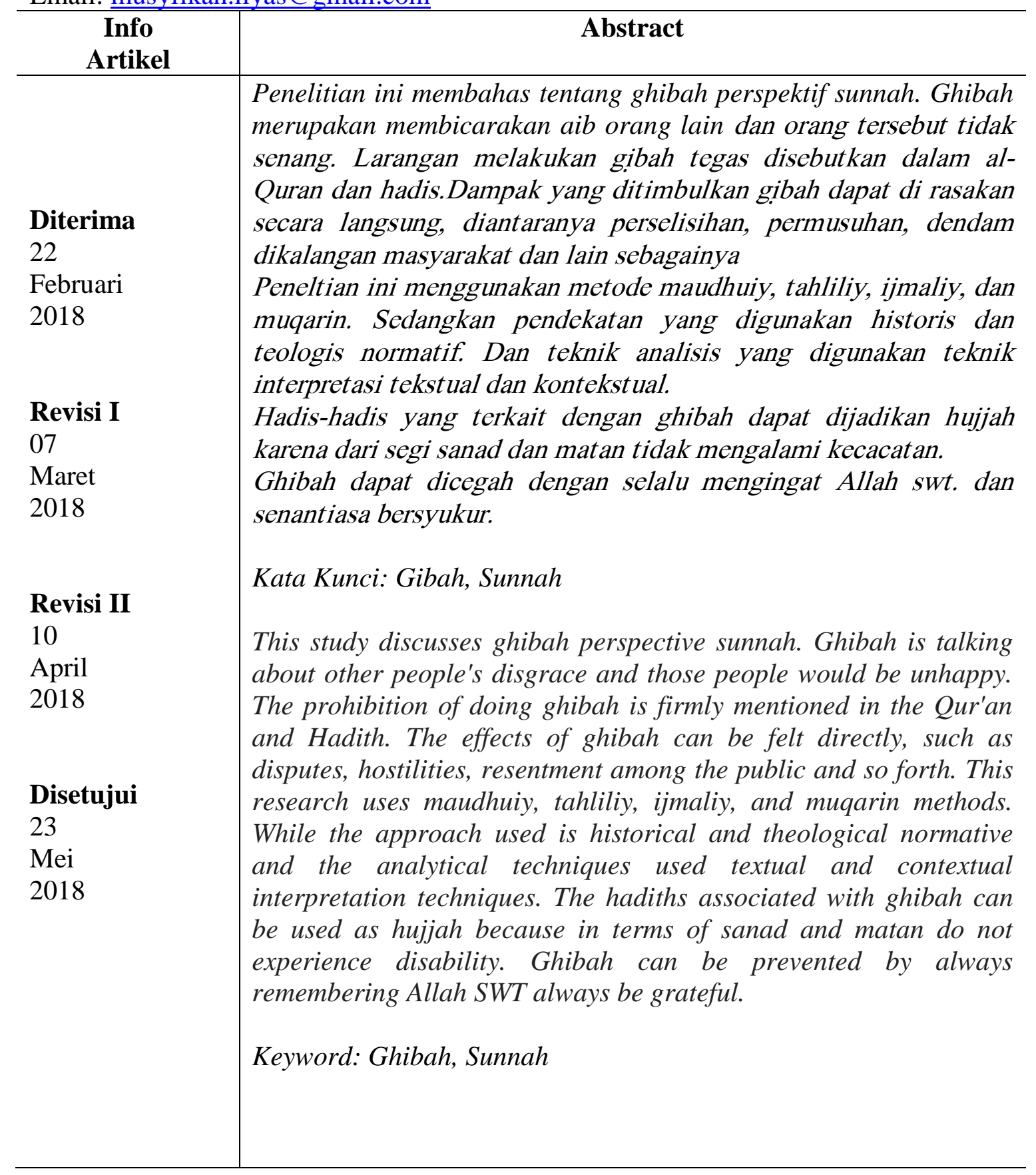




\section{A. PENDAHULUAN}

Manusia diciptakan oleh Allah swt. agar menjadi khalifah di muka bumi. Salah satu ciri khalifah adalah mampu menciptakan suasana keamanan dan kedamaian yang dapat dirasakan oleh semua pihak, baik manusia, hewan maupun alam semesta. Dan salah satu cara menciptakan kedamaian dan keamanan adalah menumbuhkan rasa saling menghargai dan saling menghormati privasi masing-masing dan menghindari hal-hal yang dapat menguak dan membuka jendela permusuhan.

Di antara sifat atau perangai negatif yang muncul dari lidah adalah dusta, buruk sangka, adu domba, bertengkar, bermusuhan, mengutuk, bersenda-gurau yang berlebihan, menghina, berdebat kusir dan ghibah (menggunjing).

Gịbah adalah menceritakan seseorang dengan sesuatu yang tidak disukainya sehingga ia merupakan sifat yang tercela dan dilarang oleh agama berdasarkan alQur'an dan Hadis Nabi karena mengandung bahaya besar, baik individu maupun masyarakat. Di antara dampak negatif gibah pada individu adalah melukai hati seseorang sehingga dapat menimbulkan permusuhan. Sementara dampak negatifnya untuk masyarakat adalah mengacaukan hubungan kekeluargaan, persaudaraan dan kemasyarakatan serta menimbulkan saling curiga-mencurigai.

Namun dalam kehidupan masyarakat, banyak ditemukan model ghibah akan tetapi dianggap oleh masyarakat bukan sebagai ghibah, sebaliknya menyebutkan aib seseorang dengan tujuan yang baik namun masyarakat menganggap sebagai pencemaran nama baik orang, seperti saling melaporkan dipihak berwajib dengan dalih pencemaran nama baik bahkan menjadi tontonan yang biasa-biasa saja di acara televisi.

Maraknya acara infotaiment di berbagai stasiun televisi, dinilai memberi dampak negatif yang berpengaruh kepada perilaku dan pola hidup masyarakat. Ketika acara infotaimen ramai menayangkan kasus perceraian misalnya, statistik perceraian di masyarakat juga meningkat. Pada saat infotaiment mempopulerkan isu perselingkuhan, ternyata di masyarakat pun ramai terjadi perselingkuhan. Memang belum diteliti secara serius hubungan antara infotaiment dengan kehidupan masyarakat, namun kasat mata menyaksikan bahwa terdapat hubungan yang cukup erat, antara tayangan televisi dengan perilaku masyarakat. Oleh karena itu, sangat penting untuk mengatahui apa sebenarnya hakikat ghibah, hukum, dampak yang ditimbulkan oleh gịbah. Salah satu cara untuk mengetahui hal tersebut adalah kembali mengkaji istilah-istilah yang muncul dalam al-Qur'an dan al-Hadis yang berkaitan dengan gibah.

\section{B. Metode, Pendekatan dan Teknik Analisis}

Peneltian ini menggunakan hadis maudhuiy maka metode yang digunakan metode maudhuiy, juga menggunakan metode tahliliy, ijmaliy, dan muqarin. Sedangkan pendekatan yang digunakan historis dan teologis normatif. Dan teknik analisis yang digunakan teknik interpretasi tekstual dan kontekstual.

\section{Takhrij Hadis \\ Metode}

Metode yang digunakan metode yang digunakan adalah menunjukkan hadis pada sumber-sumber aslinya yang telah dikeluarkan dengan sanadnya dan dapat difahami sebagai proses penelusuran hadis pada kitab-kitab yang disusun langsung oleh mukharrijnya, dan menentukan kualitas hadis tersebut, dengan penelusuran sanad hadis dengan sendirinya status hadis akan mudah diketahui. 
Sumber asli yang dimaksud dalam metode ini yaitu kitab-kitab sunnah (hadis) seperti kitab-kitab hadis (Muslim, Abu Dawud, at-Tirmidziy), dan kitab-kitab disiplin ilmu yang lain, seperti kitab-kitab tafsir, fikih, usul, sejarah dan lain-lain.

Penelusuran hadis-hadis yang ditakhrij hanya terbatas pada kitab-kitab hadis yang telah disyarah. Metode dalam menelusuri hadis-hadis yang diteliti menggunakan kitab Mu'jam al-Mufahras li Alfäz al-Hādis al-Nabawiyah, karya Arnold John Wensinck yang ditahqiq oleh Muhammad Fu'ād Abd al-Bāqi, di samping itu CD hadis sembilan Imām dan Maktabah Syamilah. Dalam penelusuran hadis-hadis yang menjadi fokus kajian dalam hal ini adalah hadis-hadis yang berhubungan dengan gibah, penulis menggunakan kata kunci yaitu الغيبة dan derivasinya. Selain itu, penulis juga langsung mencari ke kitab-kitab hadis di bab-bab penjelasan tentang gibah.

\section{Klasifikasi}

Klasifikasi tentang gịbah ${ }^{1}$ secara umum dapat dilihat pada tiga sub bahasan, yaitu:

a. Hadis tentang hakekat gibah, ditemukan sebanyak tujuh hadis, yaitu terdapat di Sahih Muslim satu riwayat, Sunan Abu Dāwud satu riwayat, Sunan at-Tirmidzi satu riwayat, Musnad Ahmad ibn Hanbal dua riwayat, Sunan al-Dārimiy satu riwayat, dan Muwatta' Imam Malik satu riwayat.

b. Hadis tentang larangan melakukan gibah terdapat empat riwayat, masing-masing ditemukan di Sunan Abu Dāwud satu riwayat, dan Musnad Ahmad ibn Hanbal tiga riwayat.

c. Hadis tentang bahaya gibah, sebanyak 20 riwayat yang terdiri dari; Sahih Bukhāriy enam riwayat, Sahih Muslim satu riwayat, Sunan al-Nasā'iy tiga riwayat, Sunan Abu Dāwud dua riwayat, Sunan at-Tirmidzīy satu riwayat, Musnad Ahmad ibn Hanbal empat riwayat, Sunan al-Dārimịy satu riwayat, dan Sunan Ibn Majah dua riwayat.

\section{I'tibar Sanad}

I'tibār sanad dilakukan untuk mengetahui gambaran umum jalur sanad hadis yang diteliti. Tujuan i'tibār untuk mengetahui kualitas hadis apakah sahih atau dhaif, bisa dijadikan hujjah atau tidak dari sudut periwayatannya, dengan meneliti jalur-jalur hadis tersebut diriwayatkan dan kesesuaiannya dengan periwayatan-periwayatan yang lain dengan jalur yang berbeda, dengan i'tibar dapat diketahui keadaan perawi dari segi terpercaya atau tidak bersambung sanadnya.

a. Hadis riwayat Muslim

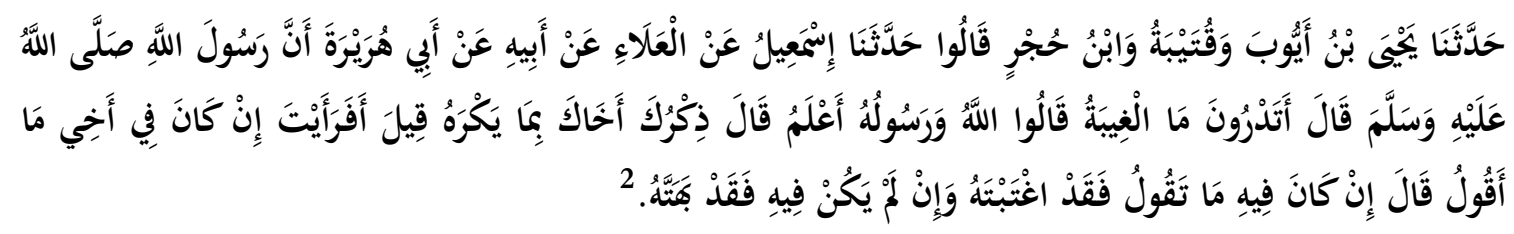

${ }^{1}$ A.J. Wensinck, al Mu’jam al Mufahras li alfăz al Hadis al Nabawi, Juz V (Leiden: E.J. Brill,1965) h. 30., Ibrahim bin Muhammad bin Kamāl al Din al Hanafi al Dimasqi, al Bayān wa al Ta'rif fi al Asbāb Wurud al Hadis al Syarif(Beirut: Dar al Ma'rifah, t.th) h. 470. Muhammad Fuad Abd. Baqi, Miftah Kunuz al Sunnah, (Bairut: Dar Ihya al Turas al Arabiy, t.th) h. 378 dan 395 Juga dapat ditelusuri dalam Kitab 9 Imam Hadits pada Lidwapusaka. 
Musyfikah Ilyas

b. Hadis riwayat at-Tirmidziy

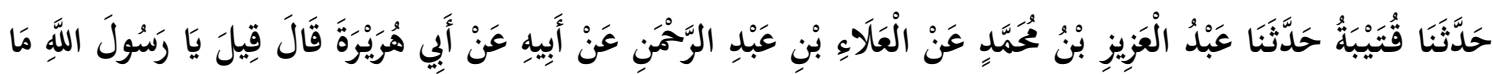

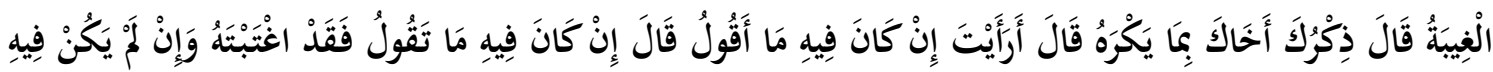

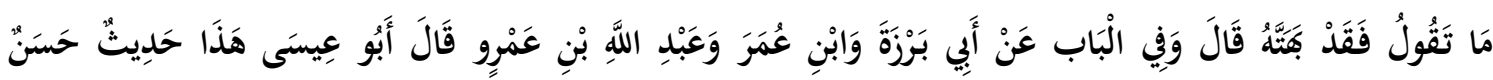

c. Hadis riwayat Abu Dāwud

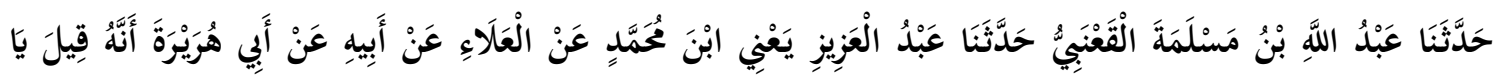

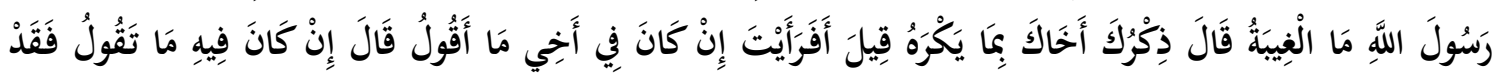

4

Skema jalur hadis hakikat gịbah

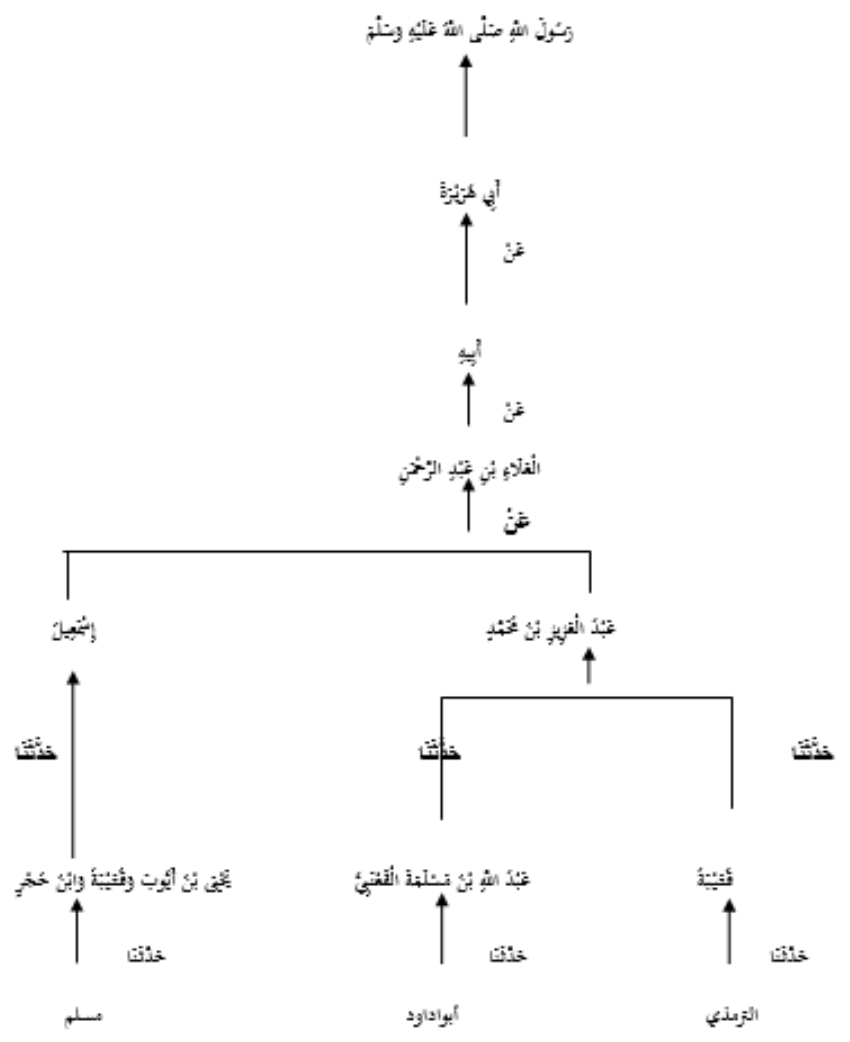
2001.

${ }^{2}$ Muhammad Fuād Abd. Al baqiy, Sahih Muslim, juz. 4 (Indonesia:Maktabah Dahlan,t.th), h.

${ }^{3}$ Imam al Hāfiz abi Isa Muhammad bin Isa bin Surah al Turmuziy, Sunan al Turmuziy al jāmiu al shahih, juz 3 (Indonesia: Maktabah Dahlan, t.th.), h. 220-221.

${ }^{4}$ Muhammad Muhyiddin abdul Hamid, Sunan Abu Dāwud, juz 4 (Indonesia: Maktabah Dahlan, t.th), h. 269. 


\section{PEMBAHASAN}

\section{Pengertian gibah}

Gịbah menurut bahasa berarti umpatan, fitnah dan gunjingan. ${ }^{5}$ Kemudian kata "umpatan" dalam kamus bahasa Indonesia dapat diartikan sebagai perkataan yang memburuk-burukkan orang lain. ${ }^{6}$ Dapat pula diartikan penggunjingan yang diidentikkan dengan kata gosip, yaitu kata negatif tentang seseorang. ${ }^{7}$ G̣ibah diidentikkan dengan umpatan, pergunjingan dan gosip.

Gịbah adalah bahasa Arab dan telah populer di kalangan masyarakat muslim Indonesia. Kata ini berasal dari tiga huruf yaitu: ب غ yang mempunyai arti dasar sesuatu yang tersembunyi dari mata. ${ }^{8}$ Dari kata ini, terciptalah kata al-gaib yang berarti sesuatu yang tidak nampak, dan al-gibah. merupakan istilah yang menunjukkan kepada hal yang membicarakan tentang keburukan atau aib seseorang yang tidak ada. ${ }^{9}$ Dan orang yang dibicarakan tidak senang dan tidak ada di tempat pembicaraan berlansung. Sesuai batasan yang diberikan oleh hadis nabi seperti yang telah disebutkan. Informasi yang membicarakan tentang gosip seseorang dapat dikategorikan dalam gịbah, khususnya yang berhubungan dengan masalah privatisasi seseorang; pribadi dan keluarganya, serta semua yang berhubungan dengan dirinya, seperti agama, harta, keturunan, bahkan termasuk gịbah pembicaraan tentang aib antara kelompok masyarakat.

Pengertian di atas, dapat disimpulkan bahwa sesuatu obrolan dapat dikatakan gịbah bila orang yang dibicarakan tidak ada dan obyek pembicaraan tentang kekurangan atau aib seseorang dan orang tersebut tidak rela dengan pembicaraan itu.

\section{Landasan Normatif}

Al-Quran

Ayat ini merupakan landasan normatif tentang gibah. ${ }^{10}$ QS. al-Hujurat (49) : 12
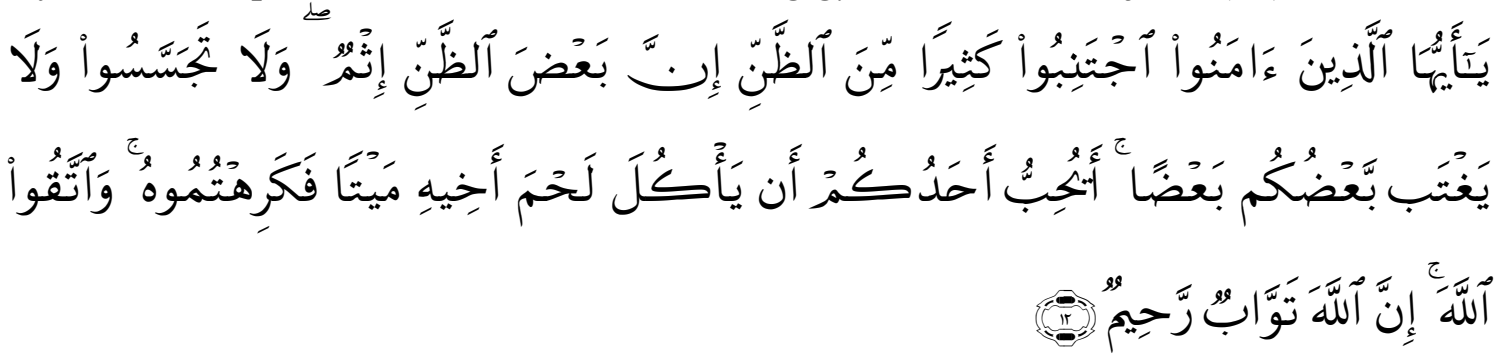

${ }^{5}$ Ahmad Warson Munawir, al-Munawwir; Kamus Arab Indonesia (Cet. IV; Yogyakarta: pustaka rogressif, 1997), h. 1025

${ }^{6}$ WJS. Poerwadarminta, Kamus Umum Bahasa Indonesia (Cet. VII; Jakarta: PN. Balai Pustaka, 1985), h. 1125.

${ }^{7}$ WJS. Poerwadarminta, Kamus Umum Bahasa Indonesia.

${ }^{8} \mathrm{Abū}$ al-Husein Ahmad ibn Fāris ibn Zakarīya, Mu'jam Maqāyīs al-Lugah (Cet. I; Beirut: Dār al Fikr, 1994), h. 818.

${ }^{9}$ Jamāl al-Dīn Muhammad ibn Makram al-Manșūr, Lisān al-'Arab, jilid 5 (Cairo: Dār alMa‘āirif, t.th.), h. 3323.

${ }^{10}$ Ahmad Mustafa Qasīm al-Tahtāwiy, Mu'jam al-Maudhuiy li Ayatal-Quran al-Karim (Kairo : Dar al-Fadhīilah, 2006), h. 454. 
Artinya :

Hai orang-orang yang beriman, jauhilah kebanyakan purba-sangka (kecurigaan), karena sebagian dari purba-sangka itu dosa. dan janganlah mencari-cari keburukan orang dan janganlah menggunjingkan satu sama lain. Adakah seorang diantara kamu yang suka memakan daging saudaranya yang sudah mati? Maka tentulah kamu merasa jijik kepadanya. dan bertakwalah kepada Allah. Sesungguhnya Allah Maha Penerima taubat lagi Maha Penyayang.

Dijelaskan juga dalam QS. al-Humazah (104) : 1

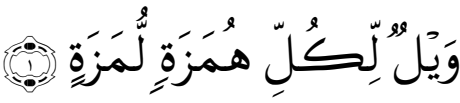

Artinya : kecelakaanlah bagi Setiap pengumpat lagi pencela

Hadis

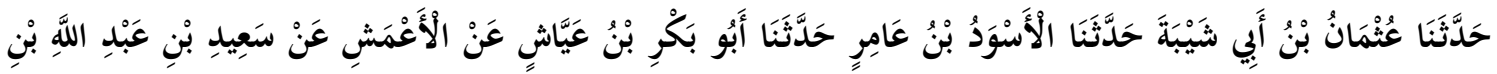

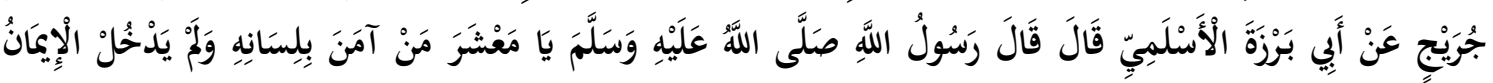

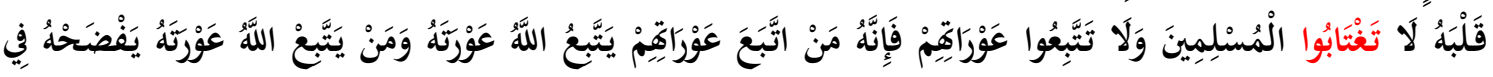

Artinya :

Telah menceritakan kepada kami Utsman ibn Abu Syaibah berkata, telah menceritakan kepada kami Al Aswad ibn Amir berkata, telah menceritakan kepada kami Abu Bakar ibn Ayyasy dari Al A'masy dari Sa'id ibn Abdullah ibn Juraij dari Abu Barzah Al Aslami ia berkata, "Rasulullah shallallahu 'alaihi wasallam bersabda: "Wahai orang-orang yang beriman lisannya namun keimanannya belum masuk ke dalam hatinya, janganlah kalian mengumpat seorang muslim dan jangan pula mencari-cari kesalahannya. Sebab siapa saja yang mencari-cari kesalahan mereka, maka Allah akan mencari-cari kesalahannya. Maka siapa saja yang Allah telah mencari-cari kesalahannya, Allah tetap akan menampakkan kesalahannya meskipun ia ada di dalam rumahnya."

\section{Doktrin/ Ijtihad}

Majelis Ulama Indonesia (MUI) mengeluarkan fatwa haram untuk infotainment baik bagi yang menayangkan maupun menonton. Fatwa tersebut disahkan dalam pleno MUI dalam Musyawarah Nasional (Munas) di Jakarta, oleh Ketua Komisi Fatwa MUI, Maruf Amin. Menurut ketentuan umum fatwa mengenai infotainment, menceritakan aib, kejelekan gosip, dan hal-hal lain terkait pribadi kepada orang lain dan atau khalayak hukumnya haram. Dalam rumusan fatwa tersebut juga disebutkan upaya membuat berita yang mengorek dan membeberkan aib, kejelekan gosip juga haram. Begitu juga dengan mengambil keuntungan dari berita yang berisi tentang aib dan

\footnotetext{
${ }^{11}$ Maktabah Syamilah, Sunan Abỉ Daud, Bab Ghibah, Juz 13, h.23. Hadis 4236. Lihat juga Muhammad Muhyiddin abdul Hamid, op.cit, h. 270.
} 
gosip dinyatakan hukumnya haram oleh MUI. Namun MUI memperbolehkan dengan pertimbangan yang dibenarkan secara syar'i untuk kepentingan penegakan hukum, memberantas kemungkaran untuk menayangkan dan menyiarkan serta menonton, membaca dan atau mendengarkan berita yang berisi tentang aib.

Perundang-Undangan

Pasal 310 ayat (1) (2) KUHP

(1) Barang siapa sengaja menyerang kehormatan atau nama baik seseorang dengan menuduhkan sesuatu hal, yang maksudnya terang supaya hal itu diketahui umum, diancam karena pencemaran dengan pidana penjara paling lama sembilan bulan atau pidana denda paling banyak empat ribu lima ratus rupiah"

(2) Jika hal itu dilakukan dengan tulisan atau gambaran yang disiarkan, dipertunjukkan atau ditempelkan di muka umum, maka diancam karena pencemaran tertulis dengan pidana penjara paling lama satu tahun empat bulan atau pidana denda paling banyak empat ribu lima ratus rupiah"

Pasal 27 ayat (1) (2) (3) (4) UU ITE

(1) Setiap orang dengan sengaja dan tanpa hak mendistribusikan dan/atau mentransmisikan dan/atau membuat dapat diaksesnya Informasi Elektronik dan/atau Dokumen Elektronik yang memiliki muatan yang melanggar kesusilaan"

(2)Setiap mentransmisikan dan/atau membuat dapat diaksesnya Informasi Elektronik dan/atau Dokumen Elektronik yang memiliki muatan perjudian.

(3)Setiap mentransmisikan dan/atau membuat dapat diaksesnya Informasi Elektronik dan/atau Dokumen Elektronik yang memiliki muatan penghinaan dan/atau pencemaran nama baik.

(4)Setiap mentransmisikan dan/atau Orang dengan sengaja dan tanpa hak Mendistribusikan dan/atau Orang dengan sengaja dan tanpa hak mendistribusikan dan/atau Orang dengan sengaja dan tanpa hak mendistribusikan dan/atau Orang dengan Dokumen Sengaja dan/atau Elektronik dan membuat yang tanpa dapat diaksesnya memiliki hak mendistribusikan muatan Informasi pemerasan dan/atau Elektronik dan/atau pengancaman.

Pasal 45 UU ITE

(1) Setiap Orang yang memenuhi unsur sebagaimana dimaksud dalam Pasal 27 ayat (1), ayat (2), ayat (3), atau ayat (4) dipidana dengan pidana penjara paling lama 6 (enam) tahun dan/atau denda paling banyak Rp1.000.000.000,00 (satu miliar rupiah).

\section{Deskripsi Sanad dan Matan Hadis}

1. Hadis tentang hakikat Gịbah

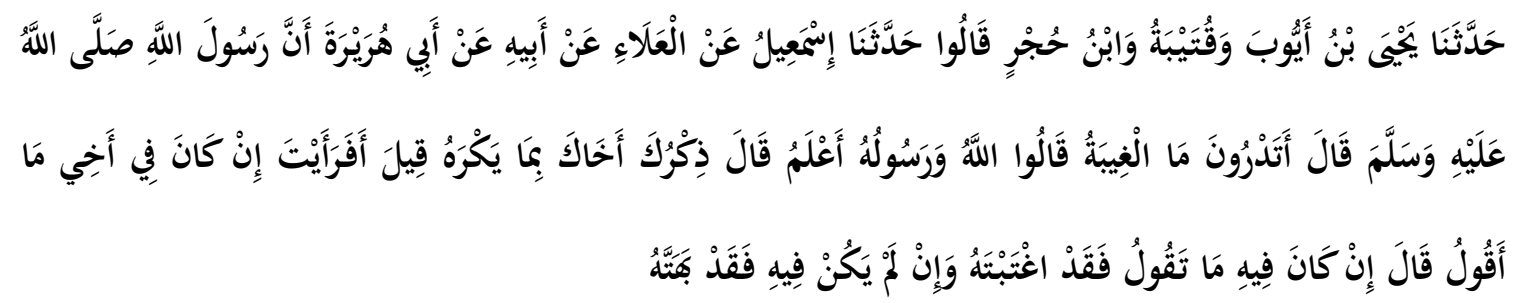


2. Hadis tentang larangan (hukum) Gịbah

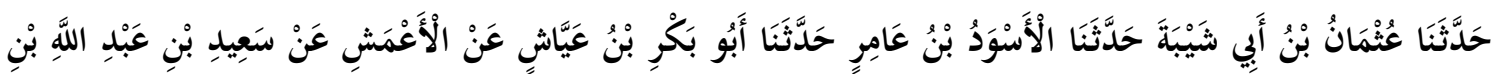

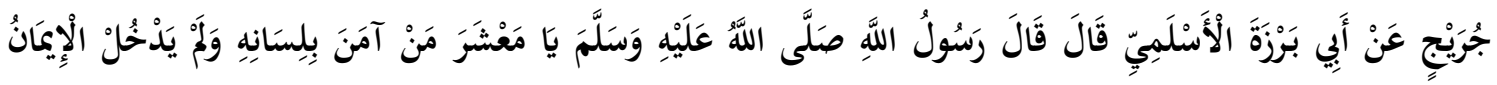

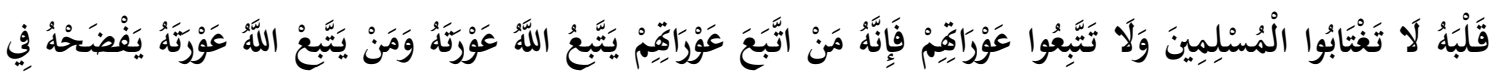
بَيْنِdِ.

3. Hadis tentang dampak Gịbah

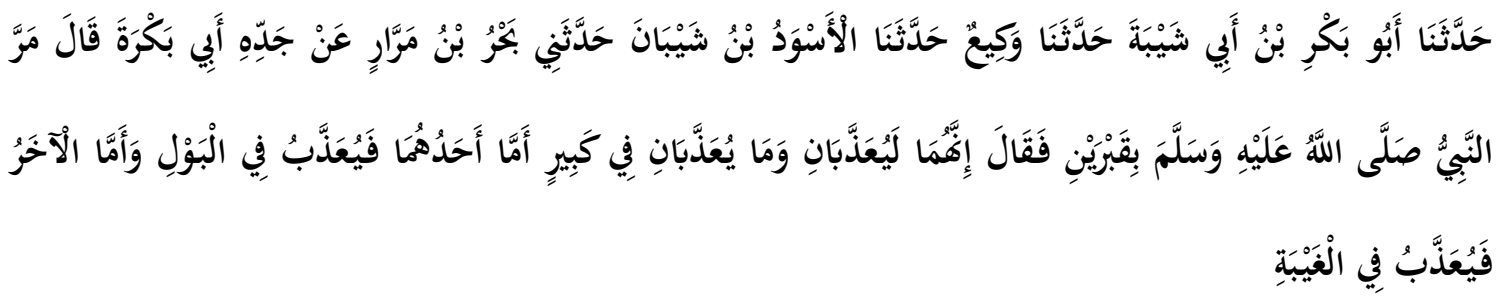

\section{Kritik Hadis}

1. Kritik Sanad

Kritik sanad dibutuhkan untuk mengetahui kualitas sanad dan yang diteliti hadis tentang hakikat gịbah melalui jalur at-Tirmidzi.

a. At- Tirmidzi ${ }^{12}$

Nama lengkapnya Muhammad bin 'Isa bin Saurah bin Musa bin adl Dlahhak, gelarannya "Abu "Isa" beliau di lahirkan (Tirmidz), yaitu satu kota yang terletak di arah selatan dari sungai Jaihun, bagian selatan Iran tanggal lahir para pakar sejarah tidak menyebutkan tahun kelahiran beliau secara pasti, akan tetapi sebagian yang lain memperkirakan bahwa kelahiran beliau pada tahun 209 hijriah. Sedang Adz Dzahabi berpendapat dalam kisaran tahun 210 hijriah.

Guru-guru beliau Imam At- Tirmidzi menuntut ilmu dan meriwayatkan hadits dari ulama-ulama kenamaan. Di antara mereka adalah: Qutaibah bin Sa'id, Ishaq bin Rahuyah, Muhammad bin 'Amru As Sawwaq al Balkhi, Mahmud bin Ghailan, Isma'il bin Musa al Fazari, Ahmad bin Mani', Abu Mush'ab Az Zuhri, Basyr bin Mu'adz al Aqadi, Al Hasan bin Ahmad bin Abi Syu'aib, Abi 'Ammar Al Husain bin Harits, Abdullah bin Mu'awiyyah al Jumahi, 'Abdul Jabbar bin al 'Ala, Abu Kuraib, 'Ali bin Hujr, 'Ali bin sa'id bin Masruq al Kindi, 'Amru bin 'Ali al Fallas, 'Imran bin Musa al Qazzaz, Muhammad bin aban al Mustamli, Muhammad bin Humaid Ar Razi, Muhammad bin 'Abdul A'la, Muhammad bin Rafi', Imam Bukhari, Imam Muslim, Abu Dawud, Muhammad bin Yahya al 'Adani, Hannad bin as Sari, Yahya bin Aktsum, Yahya bun Hubaib, Muhammad bin 'Abdul Malik bin Abi Asy Syawarib, Suwaid bin Nashr al Marwazi, Ishaq bin Musa Al Khathami, Harun al Hammal, dan yang lainnya.

\footnotetext{
${ }^{12}$ Boigrafi Kitab 9 Imam Hadis pada Lidwapusaka.
} 
Murid-murid beliau kumpulan hadits dan ilmu-ilmu yang di miliki imam Tirmidzi banyak yang meriwayatkan, diantaranya adalah: Abu Bakr Ahmad bin Isma'il As Samarqandi, Abu Hamid Abdullah bin Dawud Al Marwazi, Ahmad bin 'Ali bin Hasnuyah al Muqri, Ahmad bin Yusuf An Nasafi, Ahmad bin Hamduyah an Nasafi, Al Husain bin Yusuf Al Farabri, Hammad bin Syair Al Warraq, Dawud bin Nashr bin Suhail Al Bazdawi, Ar Rabi' bin Hayyan Al Bahili, Abdullah bin Nashr saudara Al Bazdawi, 'Abd bin Muhammad bin Mahmud An Safi, 'Ali bin 'Umar bin Kultsum as Samarqandi, Al Fadhl bin 'Ammar Ash Sharram, Abu al 'Abbas Muhammad bin Ahmad bin Mahbub, Abu Ja'far Muhammad bin Ahmad An Nasafi, Abu Ja'far Muhammad bin sufyan bin An Nadlr An Nasafi al Amin, Muhammad bin Muhammad bin Yahya Al Harawi al Qirab, Muhammad bin Mahmud bin 'Ambar An Nasafi, Muhammad bin Makki bin Nuh An Nasafai, Musbih bin Abi Musa Al Kajiri, Makhul bin al Fadhl An Nasafi, Makki bin Nuh,Nashr bin Muhammad bi Â Sabrah, Al Haitsam bin Kulaib, dan yang lainnya.

Persaksian para ulama terhadap keilmuan dan kecerdasan imam at- Tirmidzi sangatlah banyak, diantaranya adalah:

a) Imam Bukhari berkata kepada imam At- Tirmidzi; ilmu yang aku ambil manfaatnya darimu itu lebih banyak ketimbang ilmu yang engkau ambil manfaatnya dariku."

b) Al Hafiz 'Umar bin 'Alak menuturkan; Bukhari meninggal, dan dia tidak meninggalkan di Khurasan orang yang seperti Abu 'Isa dalam hal ilmu, hafalan, wara' dan zuhud."

c) Ibnu Hibban menuturkan; Abu 'Isa adalah sosok ulama yang mengumpulkan hadits, membukukan, menghafal dan mengadakan diskusi dalam hal hadits."

d) Abu Ya'la al Khalili menuturkan; Muhammad bin 'Isa at Tirmidzi adalah seorang yang tsiqah menurut kesepatan para ulama, terkenal dengan amanah dandan keilmuannya.

e) Abu Sa'd al Idrisi menuturkan; Imam Tirmidzi adalah salah seorang imam yang di ikuti dalam hal ilmu hadits, beliau telah menyusun kitab al jami', tarikh dan 'ilal dengan cara yang menunjukkan bahwa dirinya adalah seorang alim yang kapabel. Beliau adalah seorang ulama yang menjadi contoh dalam hal hafalan."

f) Al Mubarak bin al Atsram menuturkan; Imam Tirmidzi merupakan salah seorang imam hafizh dan tokoh."

g) Al Hafizh al Mizzi menuturkan; Imam Tirmidzi adalah salah seorang imam yang menonjol, dan termasuk orang yang Allah jadikan kaum muslimin mengambil manfaat darinya.

h) Adz Dzahabi menuturkan; Imam Tirmidzi adalah seorang hafizh, alim, imam yang kapabel

i) Ibnu Katsir menuturkan: Imam Tirmidzi adalah salah seorang imam dalam bidangnya pada zaman beliau."

Wafatnya beliau di akhir kehidupannya, imam at Tirmidzi mengalami kebutaan, beberapa tahun beliau hidup sebagai tuna netra, setelah itu imam atTirmidzi meninggal dunia. Beliau wafat di Tirmidz pada malam Senin 13 Rajab tahun $279 \mathrm{H}$ bertepatan dengan 8 Oktober 892 , dalam usia beliau pada saat itu 70 tahun. 
b. Qutaibah ${ }^{13}$

a) Nama Lengkap : Qutaibah bin Sa'id bin Jamil bin Tharif bin 'Abdullah

b) Kalangan : Tabi'ul Atba' kalangan tua

c) Kuniyah : Abu Raja'

d) Negeri semasa hidup : Himsh

e) Wafat : $240 \mathrm{H}$

\begin{tabular}{|l|l|}
\hline \multicolumn{1}{|c|}{ ULAMA } & \multicolumn{1}{c|}{ KOMENTAR } \\
\hline Abu Hatim & Tsiqah \\
\hline An Nasa'i & Tsiqah \\
\hline Yahya bin Ma'in & Tsiqah \\
\hline Ibnu Hajar al 'Asqalani & Tsiqah Tsabat \\
\hline
\end{tabular}

c. Abdul Azis ibn Muhammad ${ }^{14}$

Nama lengkapnya Abdul 'Aziz bin Muhammad bin 'Ubaid bin Abi 'Ubaid. Beliau lahir dan besar serta memperoleh ilmu dan hadis di Madinah. Berasal dari Tabi'ut Tabi'in kalangan pertengahan Tidak pernah keluar dari Madinah sampai beliau wafat pada tahun $187 \mathrm{H}$.

Guru-gurunya, antara lain: Ibrahim ibn Uqbah, Usamah ibn Zaid, Ja'far ibn Muhammad, al-'Alā ibn 'Abd al-Rahman ibn Ya'kub.

Murid-muridnya antara lain: Abu Ishaq Ibrahim ibn Ishaq al-Taliqaniy, Dawud ibn Abdullah al-Ja'fariy, Basyar al-Naisaburiy, Sufyan al-Zauriy (lebih tua dari beliau), Suwaid ibn Sa'id, 'Abdullah ibn Maslamah al-Qa'nabiy, 'Aliy ibn al-Madiniy.

Pendapat para kritikus hadis tentang beliau:

d. Al-A'la ${ }^{15}$

\begin{tabular}{|l|l|}
\hline ULAMA & KOMENTAR \\
\hline Yahya bin Ma'in & laisa bihi bas \\
\hline Abu Zur'ah & buruk hafalan \\
\hline Ibnu Hibban & disebutkan dalam 'ats tsiqaat \\
\hline Al 'Ajli & Tsiqah \\
\hline
\end{tabular}

Nama lengkapnya Al 'Alaa' bin 'Abdur Rahman bin Ya'qub berasal dari kalangan tabiin biasa, biasa juga disebut Abu Syubul hidup di Madinah Wafat $132 \mathrm{H}$.

${ }^{13}$ Biografi Kitab 9 Imam Hadis pada Lidwapusaka. Lihat juga Al-Ḥāfiz Abu al-Faḍl Ahmad ibn Ali ibn Hajar Syihab al-Dīn al-'Asqalānìy, Tahzīib al-Tahzīib, juz III, (Beirut: Muassasah al-Risalah, 1996). h. 431.

${ }^{14}$ Biografi Kitab 9 Imam Hadis pada Lidwapusaka. Lihat juga Al-Hāầ al-Mutqin Jamāl al-Dīn Abū al-Hajjāj Yūuf al-Mazyì, Tahzīb al-Kamal fi Asmā al-Rijăl, juz 18 (Cet. I; Beirut: Muassasah alRisālah, 1992), h. 187-194.

${ }^{15}$ Biografi Kitab 9 Imam Hadits pada Lidwapusaka . Lihat juga Al-Hạafiz Abu al-Faḍl Ahmad ibn Ali ibn Hajar Syihab al-Dīn al-'Asqalānìy, op.cit., juz III, h. 345-346. 
Guru-gurunya antara lain: Anas ibn Malik, ayahnya Abd Rahman ibn Ya'kub, Ma'bad ibn Ka'b ibn Malik, 'Ikrimah. Murid-muridnya, antara lain: Ibn Juraij, Ibn Ishaq, Malik, Fulaih, Sulaiman ibn Bilāl, Syu'bah, Muslim ibn Khalid al-Zinjịy, Ismail ibn Ja'far.

Pendapat Ulama tentang beliau

\begin{tabular}{|l|l|}
\hline ULAMA & KOMENTAR \\
\hline Ibnu 'Adi & Aku tidak melihat dia memiliki masalah \\
\hline Nasa'i & Laisa bihi ba's \\
\hline Ibnu Hibban & Mentsiqahkannyanya \\
\hline Abu Hatim Ar Rozy & $\begin{array}{l}\text { "Shalih, perawi tsiqah meriwayatkan darinya } \\
\text { dan aku mengingkari haditsnya" }\end{array}$ \\
\hline Tirmidzi & Tsiqah menurut ahli hadits \\
\hline Ahmad bin Hambal & $\begin{array}{l}\text { "Tsiqah, aku tidak pernah mendengar } \\
\text { seseorang menyebutnya dengan keburukan" }\end{array}$ \\
\hline
\end{tabular}

e. Abihi (Abdur Rahman) ${ }^{16}$

Nama lengkapnya Abdur Rahman bin Ya'qub berasal dari Tabi'in kalangan pertengahan tinggal di Madinah

Guru-gurunya, antara lain: ayahnya, Abū Hurairah, Abū Sa'id, Ibn 'Abbas, Ibn Umar Hāni maula ‘Ali.

Murid-muridnya: Anaknya al-'Alā, Sālim Ab- Najr, Muhmmad ibn Ibrahim alTaymịy, Muhammad al-'Ajlān, Muhammad ibn 'Amr ibn 'Alqamah, Umar ibn Hafs akwān.

Pendapat ulama tentang beliau, antara lain:

\begin{tabular}{|l|l|}
\hline ULAMA & KOMENTAR \\
\hline Al 'Ajli & Tsiqah \\
\hline An Nasa'i & laisa bihi bas \\
\hline Ibnu Hibban & disebutkan dalam 'ats tsiqaat \\
\hline Ibnu Hajar al 'Asqalani & Tsiqah \\
\hline Adz Dzahabi & Tsiqah \\
\hline
\end{tabular}

\section{f. Abu Hurairah ${ }^{17}$}

Nama lengkapnya Abdur Rahman bin Shakhr, dan nama beliau di masa jahiliyah Abd Syams. Beliau adalah sahabat Rasulullah saw. mayoritas mengatakan beliau meninggal tahun $58 \mathrm{H}$.

\footnotetext{
${ }^{16}$ Biografi Kitab 9 Imam Hadis pada Lidwapusaka. Lihat juga Al-Hạậ Abu al-Fạ̣l Ahmad ibn Ali ibn Hajar Syihab al-Dīn al-'Asqalāniy, Ibid., Juz II, h. 567.

${ }^{17}$ Biografi Kitab 9 Imam Hadis pada Lidwapusaka. Lihat juga Al-Hạâz Abu al-Faụl Ahmad ibn Ali ibn Hajar Syihab al-Dīn al-‘Asqalāniy Ibid., juz IV, h. 601-602.
} 
Pendapat Ulama

\begin{tabular}{|l|l|}
\hline \multicolumn{1}{|c|}{ ULAMA } & \multicolumn{1}{c|}{ KOMENTAR } \\
\hline Ibnu Hajar al 'Asqalani & Shahabat \\
\hline
\end{tabular}

Uraian diatas maka dapat disimpulkan bahwa hadis tentang gịbah yang diriwayatkan oleh abdul Aziz ibn Muhammad dan al-'Alā ibn Abdur Rahman dapat diterima, karena kritik terhadap mereka dari kritik sanad dikatakan laisa bihỉ bas itulah kritikan yang paling rendah dan hadis diriwayatkan dari beberapa jalur dan bertemu di al-`Alā, dan menurut Imam Ahmad bin Hambal dan perawi lainnya menilainya ziqah. Maka hadis yang diriwayatkan at-Tirmizìy bisa dikatakan shahih li gairihì dan dapat dijadikan hujjah.

\section{Kritik matan}

Kritik matan hadis tentang gịbah yang diriwayatkan Muslim, at- Tirmidzi dan Abu Dawud. Kalau hadis yang diriwayatkan Muslim Rasulullah yang bertanya kepada sahabat أَتَرْرُونَ مَا الْغِيبَة (Tahukah kamu, apakah gibah itu), dan pada riwayat At-Tirmidzi dan Abū Dawud sahabat yang bertanya kepada Rasulullah saw يَا رَسُولَ اللَّهِ مَا الْغِيبَة (Ya Rasulullah apa gibah itu). Kritik matan tentang hadis hakikat gịbah tidak ada perbedaan dari segi subtansi maknanya, sehingga dapat dijadikan hujjah dan periwayatannya bil ma'na.

Syarah Hadis

1. Hadis tentang gịbah

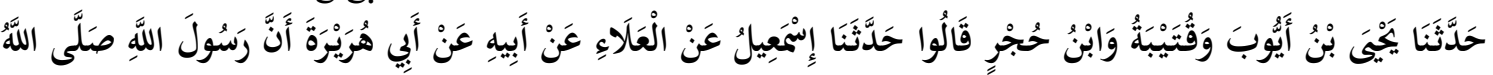

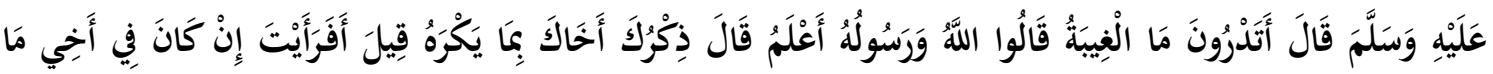

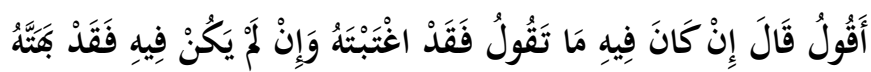

Artinya:

Telah menceritakan kepada kami Yahya ibn Ayyub, Qutaibah dan Ibnu Hujr mereka berkata; Telah menceritakan kepada kami Isma'il dari Al A'laa dari Bapaknya dari Abu Hurairah bahwa Rasulullah shallallahu 'alaihi wasallam pernah bertanya: "Tahukah kamu, apakah ghibah itu?" Para sahabat menjawab; 'Allah dan Rasul-Nya lebih tahu.' Kemudian Rasulullah shallallahu 'alaihi wasallam bersabda: 'Ghibah adalah kamu membicarakan saudaramu mengenai sesuatu yang tidak ia sukai.' Seseorang bertanya; 'Ya Rasulullah, bagaimanakah menurut engkau apabila orang yang saya bicarakan itu memang sesuai dengan yang saya ucapkan? ' Rasulullah shallallahu 'alaihi wasallam berkata: 'Apabila benar apa yang kamu bicarakan itu ada padanya, maka berarti kamu telah menggunjingnya. Dan apabila yang kamu bicarakan itu tidak ada padanya, maka berarti kamu telah membuatbuat kebohongan terhadapnya.' 
Hakikat gịbah kamu membicarakan saudaramu mengenai sesuatu yang ia tidak sukai. Dari proses tanya- jawab yang dilakukan Rasulullah saw dan sahabat dalam hadis ini adalah salah satu bentuk etika atau tata krama dalam majlis Rasulullah saw. ${ }^{18}$

Hadis di atas menjelaskan gambaran tentang gịbah adalah pengungkapan yang dilakukan seorang muslim mengenai diri sesamanya muslim yang apabila didengar menimbulkan rasa benci ${ }^{19}$ dapat juga dimaknai gibah yaitu menyebutkan sesuatu yang terdapat pada diri seorang muslim, padahal ia tidak suka bila disebutkan. ${ }^{20}$

Berdasarkan uraian diatas dipahami gịbah merupakan pengungkapan aib atau cacat seseorang baik yang dilakukan secara lisan, tulisan, isyarat maupun gerakan yang dapat dipahami maksudnya sebagai bentuk penghinaan atau merendakan derajatnya, dan apabila yang didengar atau diketahui oleh orang yang digunjing itu timbul rasa permusuhan, malu dan sebagainya.

2. Hadis tentang larangan (hukum) melakukan gịbah

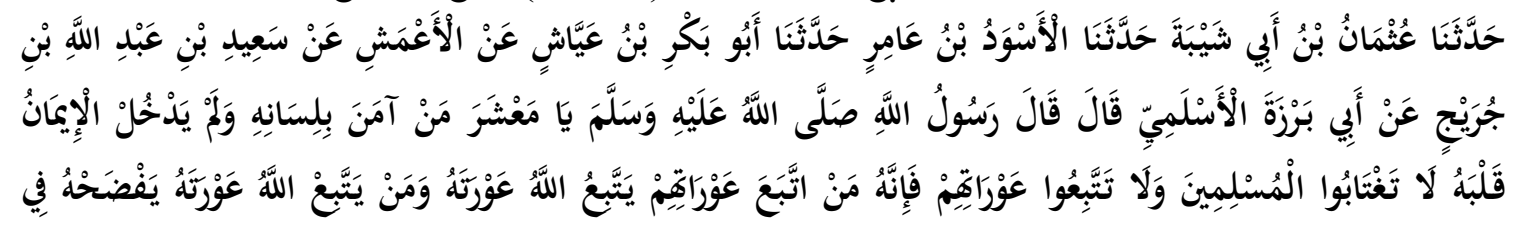

Artinya:

Telah menceritakan kepada kami Utsman ibn Abu Syaibah berkata, telah menceritakan kepada kami Al Aswad ibn Amir berkata, telah menceritakan kepada kami Abu Bakar ibn Ayyasy dari Al A'masy dari Sa'id ibn Abdullah ibn Juraij dari Abu Barzah Al Aslami ia berkata, "Rasulullah shallallahu 'alaihi wasallam bersabda: "Wahai orang-orang yang beriman lisannya namun keimanannya belum masuk ke dalam hatinya, janganlah kalian mengumpat seorang muslim dan jangan pula mencari-cari kesalahannya. Sebab siapa saja yang mencari-cari kesalahan mereka, maka Allah akan mencari-cari kesalahannya. Maka siapa saja yang Allah telah mencari-cari kesalahannya, Allah tetap akan menampakkan kesalahannya meskipun ia ada di dalam rumahnya."

Hadis yang berhubungan dengan larangan melakukan gibah tersebut di atas menurut riwayat Abū Dawūd, dalam hadis tersebut Rasulullah saw. melarang kaum muslimin untuk melakukan gibah sesama kaum muslimin.

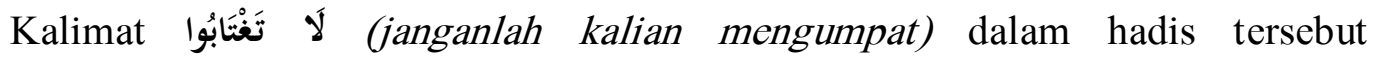
menunjukkan larangan.Dalam makna hadis "Wahai orang-orang yang beriman lisannya namun keimanannya belum masuk ke dalam hatinya, janganlah kalian mengumpat seorang muslim" sebagai peringatan bahwa perbuatan gibah termasuk sifat orang

${ }^{18}$ Muhammad Ibn 'Alān al-Ṣiddiqīi al-Syāfi'iy al-Asy’ariy al-Makkīy, Dalìl al- Fāliḥin li Ṭuruq Riyāẹ al-Ṣalihịin, Juz 4 (Beirut: Dar al-Fikr, t.th), h. 357.

${ }^{19}$ Khalil Ma'mun, al-Manhaj Syarh Shahih Shahih Muslim bin al-Hajjäj (Cet.II: Beirūt-Libanon : Dār al-Ma'rifah,1996), h. 358.

${ }^{20}$ Muhammad Shālih al-Munajjid, Muharramāt Istihanā al-Nās, diterjemahkan oleh Ainul Haris Umar Thayib dengan judul Dosa-dosa Yang Dianggap Biasa (Cet. I; Jakarta: Akafa Press, 1997),h. 103. 
munafik bukan orang mukmin, ${ }^{21}$ karena salah satu tanda munafik adalah mengaku dengan perkataannya beriman sebenarnya tidak beriman seperti ditegaskan oleh firman Allah dalam QS. Al-Baqarah (2) : 8.

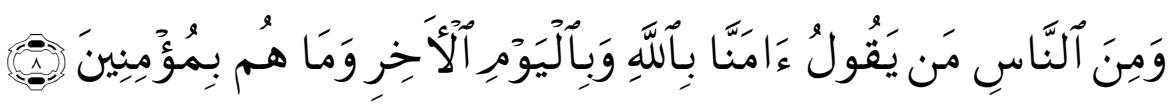

Artinya:

Di antara manusia ada yang mengatakan: "Kami beriman kepada Allah dan hari kemudian," pada hal mereka itu Sesungguhnya bukan orang-orang yang beriman.

Lain halnya dengan ijtihad ulama dalam menyikapi gịbah, pada kasus-kasus tertentu mereka membolehkannya sebagaimana hasil ijtihad Ibrahim Muhammad Jamāl yang menurutnya, menggunjing dibolehkan dalam beberapa hal sebagai berikut: ${ }^{22}$

a. Ketika menyampaikan penganiayaan orang lain kepada penguasa/ pemerintah dengan menerangkan hakikat yang sebenarnya dan menerangkan keadaan orang yang melakukannya.

b. Ketika meminta pertolongan untuk mengubah sesuatu kemungkaran yang pada saat itu diminta keterangan dan penjelasannya.

c. Ketika meminta fatwa dalam masalah terkadang membutuhkan banyak perincian bukti, bahkan sifat-sifat agar pemberi fatwa mengerti kedudukan masalah yang dibicarakan.

d. Ketika hendak memberikan peringatan dari musibah atau kefasikan yang membutuhkan penjelasan dan untuk membersihkan diri ketika ditanya tentang seorang saksi yang dianggap tidak benar dan merugikan.

e. Ketika menanyakan seseorang yang lebih dikenal dengan gelarnya.

f. Menyebutkan orang-orang yang secara terang-terangan berbuat kefasikan agar berhati-hati kepadanya.

Dengan demikian, keharaman gibah sangat kuat dan tidak menyisakan perbedaan pendapat. Dan sejauh ini tidak ditemukan pendapat yang membolehkan gibah tanpa alasan sebagaimana yang dikemukakan, dan gịbah itu dibolehkan bilamana bukan bertujuan untuk merendahkan dan mengurangi kehormatan seseorang.

3. Hadis tentang dampak gibah

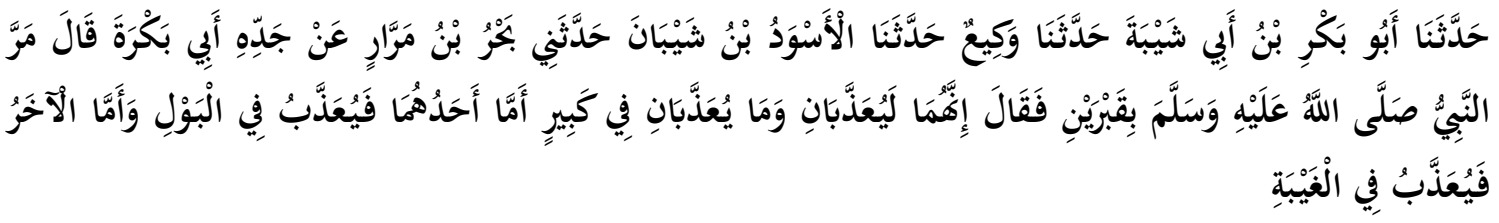

Artinya:

Telah menceritakan kepada kami Abu Bakr ibn Abu Syaibah berkata, telah menceritakan kepada kami Waki' berkata, telah menceritakan kepada kami Al Aswad ibn Syaiban berkata, telah menceritakan kepadaku Bahr ibn Mirar dari

\footnotetext{
${ }^{21}$ Muhammad Muhyiddin abdul Hamid, Sunan Abu Dāwud, h. 270.

${ }^{22}$ Ibrāhim Muhammad al-Jamāl, Amrād al-Nufüs, diterjemahkan oleh Amir Hamzah Fahcrudin dengan judul Penyakit-penyakit Hati (Cet. I; Bandung : Pustaka Hidayah, 1995), h. 109-110.
} 
kakeknya Abu Bakrah berkata; Nabi shallallahu 'alaihi wasallam melewati dua kuburan, lalu beliau bersabda: "Keduanya sedang disiksa, dan mereka disiksa bukan karena dosa besar. Yang satu disiksa karena tidak menjaga kebersihan ketika kencing dan yang lain disiksa karena berbuat ghibah".

Hadis diatas menjelaskan tentang dampak gịbah sekaligus menginformasikan tentang gibah termasuk dosa kecil. Ada beberapa ulama berbeda pendapat tentang apakah ghibah termasuk dosa besar atau hanyalah dosa kecil. Sebagian ulama berpendapat bahwa ghibah tergolong dosa besar sementara ulama yang lain mengatakan bahwa gịbah jika dilakukan oleh orang-orang yang tidak menuntut ilmu atau pengkaji al-Qur'an (masyarakat biasa) maka hanya masuk dalam kategori dosa kecil.

Gịbah merupakan perbuatan yang sangat berbahaya menurut pandangan Islam. Hal tersebut sesuai sabda Rasulullah saw yang menyatakan bahwa gịbah termasuk dosa besar : ${ }^{23}$

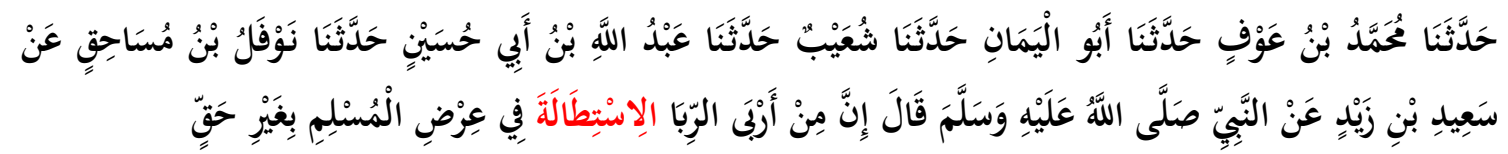

Artinya:

hadis tersebut menjelaskan bahwa gịbah itu sama dengan riba, bahkan dipandang yang paling riba dari pada riba. Dengan demikian gibah itu haram hukumnya, sebab Allah swt mengharamkan riba (QS. al-Baqarah (2): 275).

Gịbah juga dapat dilihat sebagai dosa besar pada hadis sebagai berikut :24

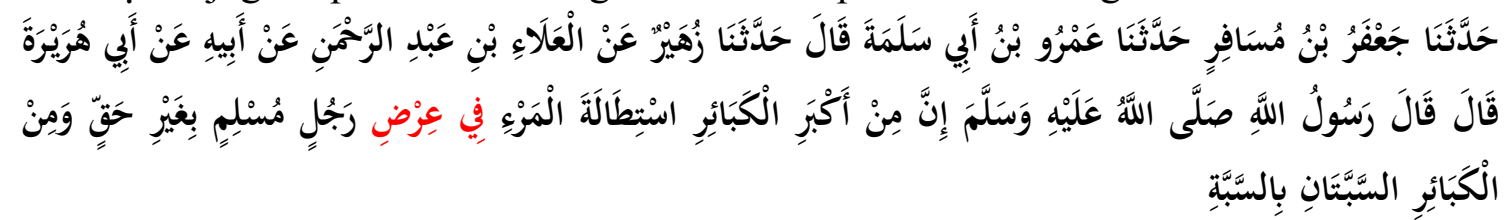

Artinya:

Rasulullah saw bersabda: yang paling besar dosa besar adalah gunjingan seseorang tentang kehormatan seseorang laki-laki muslim tanpa kebenaran.

Berdasarkan kedua hadis diatas yang menjelaskan tentang gịbah merupakan dosa besar yang melebihi riba. Oleh karena itu, menurut hadis tidak ada kemungkinan untuk membolehkan orang melakukan gịbah.

Memperhatikan ayat dan hadis-hadis yang telah dipaparkan, dapat dipahami bahwa gịbah merupakan sesuatu yang diharamkan. Meskipun terjadi perselisihan pendapat tentang apakah gịbah masuk dosa besar atau hanyalah dosa kecil, hal terpenting dari gịbah bukan terletak pada dosa besar atau dosa kecilnya akan tetapi gịbah merupakan tindakan yang dikecam, baik oleh al-Qur'an, al-Hadis maupun oleh manusia itu sendiri dan merupakan sifat yang harus dihindari oleh setiap manusia,

\footnotetext{
${ }^{23}$ Maktabah Syamilah, Kitab Sunan Abī Daud, Bab Fi al-Gibah, juz 13, hadis 4233, h.20..

${ }^{24}$ Maktabah Syamilah, Kitab Sunan Abi Daud, bab fí al Gibah, Juz 13, hadis 4234, h.21. Muhammad Muhyiddin abdul Hamid, Sunan Abu Dāwud, juz 4., h. 269.
} 
khususnya umat Islam tanpa memandang apakah orang terpelajar, intelektual atau masyarakat biasa, sebab dampak dari gịbah dapat dirasakan dan dialami oleh siapa saja. Dan siapapun pelakunya akan mendapatkan dosa dan hukuman di sisi Allah swt, sedangkan besar-kecilnya dosa itu adalah wewenang mutlak Allah swt.

Allah swt dan Rasul-Nya melarang melakukan gịbah bukan larangan belaka namun larangan tersebut ada indikasi dampak yang sangat besar yang ditimbulkan. Hal itu bisa berdampak di dunia dan akhirat.

\section{a. Di dunia}

Di antara dampak negatif ghibah adalah melukai hati seseorang sehingga dapat menimbulkan permusuhan dan mengacaukan hubungan kekeluargaan, persaudaraan dan kemasyarakatan serta menimbulkan saling curiga-mencurigai.

b. Di akhirat

1. Mendapatkan siksaan kubur.

Sebagaimana hadis di atas menjelaskan bahwa Rasulullah mendengarkan siksaan dari dalam dua kubur yang salah satunya disiksa karena dosa ghibah.

2. Menghanguskan pahala

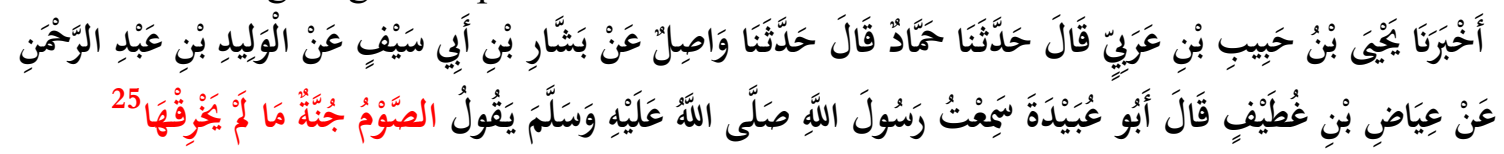

Artinya:

Puasa digambarkan bagaikan bunga atau perlindungan yang sewaktu-waktu dapat dirusak atau dibakar oleh hama ghibah.

Ghibah yang dilakukan oleh orang puasa dapat berdampak pada pahala puasa dimana ghibah akan menghabiskan pahalanya, sehingga dalam hadis tersebut dijelaskan bahwa gibah dapat menghanguskan pahala bagi orang yang sedang berpuasa.

3. Menjerumuskan ke dalam api neraka

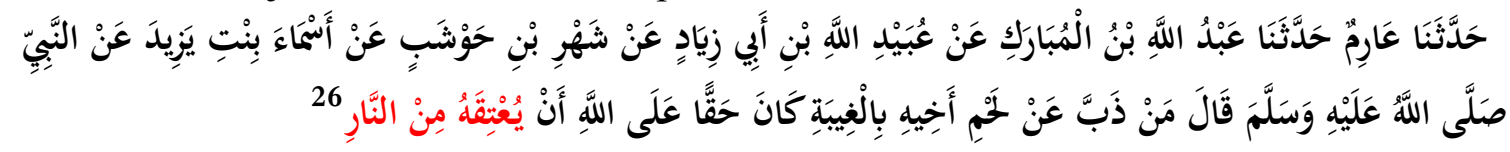

Sebenarnya dalam hadis di atas, tidak dijelaskan bahwa orang yang melakukan ghibah akan dimasukkan ke dalam api neraka, akan tetapi dapat dipahami secara terbalik (mafhum mukhalafah) bahwa orang yang menghalau atau menghindari perilaku ghibah maka Allah akan menyelamatkannya dari api neraka berarti orang yang melakukan ghibah tidak akan diselamatkan dari api neraka.

4. Mengeluarkan bau busuk di hari kiamat.

\footnotetext{
${ }^{25}$ Maktabah syamilah, Kitab Sunan an-Nasai,Bab Dzikru al-Ikhtilaf ala-Muhammad ibn Abì Ya'Qub fi, juz 7, hadis 220, h. 416.

${ }^{26}$ Maktabah syamilah, Kitab Musnad Ahmad, Bab Min Hadis Asma'a Abnati Yazìd ra, Juz 56, hadis 26327 , h. 138 .
} 


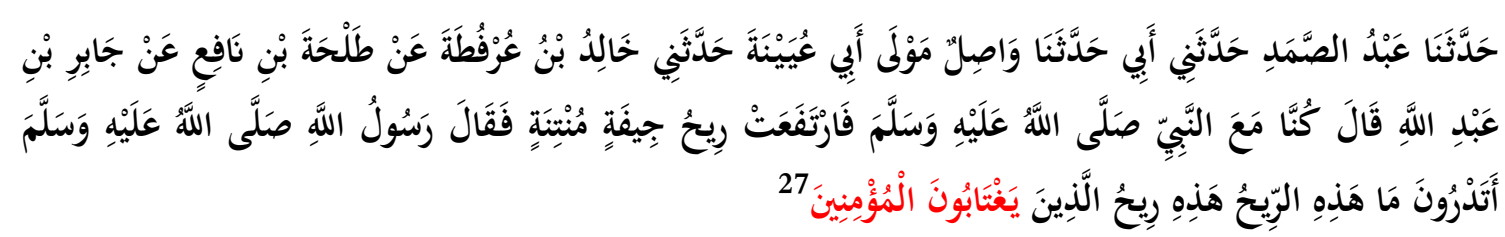

Maksud dari hadis di atas adalah salah satu sanksi yang akan diterima oleh pelaku ghibah di hari kiamat nanti adalah dia akan mengeluarkan bau bangkai busuk sebagaimana dia suka memakan bangkai pada saat masih hidup.

\section{Analisis pengembangan}

Infotaiment adalah sejenis acara televisi yang memadukan dua unsur yakni informasi dan hiburan. Acara ini mulai muncul di era 90-an dan semakin marak seiring dengan lahirnya stasiun-stasiun televisi. Karena sifatnya informatif dan menghibur, acara ini mendapatkan tempat di hati masyarakat. Hal ini ditandai dengan meningkatnya rating (peringkat atas banyaknya jumlah penonton) untuk acara sejenis ini. Sedemikian lakunya, sehingga hampir semua stasiun televisi menayangkan acara jenis ini tiap hari.

Persoalan kemudian muncul ketika acara ini yang seharusnya menginformasikan sisi positif dari seorang tokoh, dan menghibur dalam arti yang positif, bergeser kepada informasi sisi negatif dari kehidupan sang tokoh, serta hiburan yang dimanupulasi dari perseteruan, perselingkuhan, perceraian, yang disajikan dengan teknologi efek yang canggih. Pemirsapun seakan disihir dengan manipulasi kata-kata dan ungkapan-ungkapan yang memperlihatkan keprihatinan atas kasus atau perilaku negatif dari seorang tokoh. Penyajian yang manipulatif ini pun ternyata "memikat" masyarakat sehingga rating acara tetap tinggi.

Perilaku para pencari berita tersebut, mereka terkadang rela begadang di depan pagar seorang artis, menunggu berjam-jam di luar pengadilan untuk meliput perkara perceraian atau perselingkuhan seorang artis. Terkadang mereka memaksa masuk ke acara keluarga dan resepsi pernikahan tanpa diundang, atau memaksakan pertanyaanpertanyaan yang tidak layak. Tidak salah juga jika akhirnya ada tokoh atau artis yang mengatakan bahwa kehidupannya sudah "dirampas" oleh para pemburu berita tersebut.

Etika, sopan santun, dan penghargaan atas privasi seseorang menjai hilang, di sisi lain terdapat sejumlah tokoh artis yang mendapatkan keuntungan liputan acara infotainment tersebut, namun tidak sedikit yang merasa terzalimi, difitnah, sehingga kehormatannya terusik. Dan masyaakat sebagai konsumen acara ini seperti dipaksa menelan bulat-bulat informasi yang mungkin jauh dari kebenaran dan memang tidak perlu ini. Informasi dan tayangan negatif dari acara ini kemudian beradaptasi di dalam otak dan secara perlahan mengubah persepsi. Jika dulunya perceraian dan perselingkuhan menjadi aib untuk dibicarakan apalagi dilakukan, dengan perubahan persepsi ini, masyarakat sudah menganggap bahwa perceraian dan perselingkuhan menjadi hal biasa. Akibatnya, statistik perceraian dan perselingkuhan semakin meningkat. Infotaiment dengan model seperti di atas inilah yang kemudian mendominasi kebanyakan sajian acara infotaiment tanah air dan akibat buruknya yang kini semakin disadari oleh masyarakat.

${ }^{27}$ Maktabah Syamilah, Kitab Musnad Ahmad, Bab Musnad Jabir bin Abdullah ra, Juz 29 , hadis 14257 , h. 306, 
Gịbah secara tegas menghimpun segala bentuk proses informasi negatif (yang tidak disukai jika terdengar oleh obyek) dari narasumber, hingga pendengar menjadi kesatuan yang tidak dipisahkan sebagai pelaku gibah. Sementara infotanment dari faktanya sudah jelas-jelas menjadikan informasi pribadi seseorang baik yang positif maupun negatif sebagai tayangan utama.

Infotaiment cakupannya sangat luas sehingga butuh analisa pengembangan untuk memilah mana infotaiment yang sifatnya gosip dan infotaiment sifatnya informasi umum. Di sisi lain, bahwa beberapa item dan topik tayangan infotaiment bukanlah merupakan tayangan negatif atau berefek negatif. Tayangan pernikahan, kelahiran, ulang tahun, serta berbagai kegiatan positif lainnya dapat memuaskan rasa ingin tahu masyarakat tentang tokoh idolanya. Sisi baik dari seorang artis atau tokoh tentu dapat menjadi insnpirasi bagi masyarakat untuk mencontoh berbagai perilaku positif dari mereka. Tayangan seperti inilah yang seharusnya diberikan kepada masyarakat.

\section{PENUTUP}

Kesimpulan berikut:

Berdasarkan uraian diatas tentang gịbah maka dapat disimpulkan sebagai

1. Hakikat gịbah membicarakaan orang lain dan orang tersebut tidak senang, dan hadis tentang gịbah bisa dijadikan bisa dijadikan hujjah.

2. Larangan melakukan gịbah tegas disebutkan dalam al-quran dan hadis.

3. Dampak yang ditimbulkan gịbah dapat di rasakan langsung di dunia dan akhirat.

\section{Implikasi}

1. Menegaskan larangan gibah dalam acara televisi, baik infotaimen ataupun lainnya dan memberikan sanksi yang tegas bagi stasiun televisi yang melanggar larangan tersebut.

2. Mengarahkan dan mensupport media televisi untuk hanya menayangkan acara-acara yang bersifat mendidik dan menghargai kehidupan pribadi setiap warganegara.

3. Tugas para pendidik, tokoh masyarakat, cendekiawan, dan pemerhati masalah kemasyarakatan adalah melindungi masyarakat dari tontonan yang tidak perlu yang berisi gịbah. Yang dibutuhkan adalah ketegasan dan kerjasama kolektif semua pihak. Di sini, pihak penyelenggara acara infotaiment diminta untuk segera menyaring dan membatasi tema-tema berita dan tayangan yang disampaikan, agar bersih dari gịbah. 


\section{DAFTAR PUSTAKA}

Al-'Asqalānìy, Al-Ḥāiz Abu al-Faḍl Ahmad ibn Ali ibn Hajar Syihab al-Dīn. Tahzīib al-Tahzīb, juz III. Beirut: Muassasah al-Risalah, 1996.

Al baqiy, Muhammad Fuād Abd. Sahih Muslim, juz. 4. Indonesia : Maktabah Dahlan. ---------, Muhammad Fuad Abd. Miftah Kunuz al Sunnah. Bairut: Dar Ihya al Turas al Arabiy.

Al Dimasqi, Ibrahim bin Muhammad bin Kamāl al Din al Hanafi. Al Bayān wa al Ta'rif fi al Asbāb Wurud al Hadis al Syarif. Beirut: Dar al Ma'rifah.

Al-Jamāl, Ibrāhim Muhammad. Amrād al-Nufüs, diterjemahkan oleh Amir Hamzah Fahcrudin dengan judul Penyakit-penyakit Hati . Cet. I; Bandung : Pustaka Hidayah, 1995.

Al-Munajid, Muhammad Shālih. Muharramāt Istihanā al-Nās, diterjemahkan oleh Ainul Haris Umar Thayib dengan judul Dosa-dosa Yang Dianggap Biasa (Cet. I; Jakarta: Akafa Press, 1997),h. 103.

Al-Mazyī, Al-Hāifiz al-Mutqin Jamāl al-Dīn Abū al-Hajjāj Yūsuf. Tahzīb al-Kamal fi Asmā al-Rijāl, juz 18. Cet. I; Beirut: Muassasah al-Risālah, 1992.

Al-Makkīy, Muhammad Ibn 'Alān al-Șiddiqīi al-Syāfi'iy al-Asy’ariy. Dalỉ al- Fāliḥ̄in li T.uruq Riyāọ al-Ṣalihịin, Juz 4. Beirut: Dar al-Fikr.

Al-Manșūr, Jamāl al-Dīn Muhammad ibn Makram. Lisān al-'Arab, jilid 5. Cairo: Dār al-Ma‘̄arif.

Al-Tahtāwiy, Ahmad Mustafa Qasīm. Mu'jam al-Maudhuiy li Ayatal-Quran al-Karim. Kairo: Dar al-Fadhīlah, 2006), h. 454.

At- Turmuziy, Imam al Hāfiz abi Isa Muhammad bin Isa bin Surah. Sunan al Turmuziy al jāmiu al shahih, juz 3. Indonesia: Maktabah Dahlan.

Kitab 9 Imam Hadits pada Lidwapusaka.

CD Room Maktabah Syamilah.

Hamid, Muhammad Muhyiddin abdul. Sunan Abu Dāwud, juz 4. Indonesia: Maktabah Dahlan.

Ma'mun, Khalil. al-Manhaj Syarh Shahih Shahih Muslim bin al-Hajjāj. Cet.II: BeirūtLibanon : Dār al-Ma'rifah,1996.

Munawir, Ahmad Warson. al-Munawwir; Kamus Arab Indonesia. Cet. IV; Yogyakarta: pustaka rogressif, 1997.

Poerwadarminta, WJS. Kamus Umum Bahasa Indonesia. Cet. VII; Jakarta: PN. Balai Pustaka, 1985.

Wensinck, A.J. al Mu'jam al Mufahras li alfãz al Hadis al Nabawi, Juz V. Leiden: E.J. Brill, 1965.

Zakarīya, Abū al-Husein Ahmad ibn Fāris ibn. Mu'jam Maqāyīs al-Lugah . Cet. I; Beirut: Dār al Fikr, 1994. 